\title{
Intercultural aspects of concept "TOLERANCE" and facilities of creating tolerant academic environment
}

\author{
Anna Petrikova - Tamara Kuprina - Anna Beketova - Mikaela Mishenkova
}

DOI: 10.18355/XL.2017.10.04.24

\begin{abstract}
The article presents a theoretical and practical research on issues of modern terminology to show its ambivalence in general and the concept "tolerance" in particular from the intercultural linguistic paradigm point of view which is confirmed by the vivid fiction and publicistic examples; to offer the technology for integrating obtained results in creating tolerant academic environment. The analysis of the theoretical and legal bases on the issue has been done. There are numerous practical examples on ten cultures and four confessions. The technology of developing intercultural communicative tolerance in the academic environment is proposed.
\end{abstract}

Key words: ambivalence, academic environment, concept, term, tolerance, intolerance

\section{Introduction}

At present, all societies are undergoing tremendous changes requiring the comprehension of a new intercultural paradigm of education, which should not be based only on the study of individual disciplines but on the basis of research of the problems of the global world. At the same time, traditional approaches to teaching foreign languages do not sufficiently take into account their specifics such as a reflection of the cultural values system on the basis of which specific societies and models of their citizens' behavior are formed.

The involvement of the humanities for research in the natural sciences is based on various approaches. Thus, the synergetic approach allows the person to assert themselves in his/her synergetic cognitive position, which "allows penetrating into the depth of things, to go beyond the immediate impression, organize purposeful behavior, reveal complex connections and relations that are inaccessible to direct perception, transmit information to another person that is a powerful stimulus of intellectual development through the transmission of information accumulated in many generations" (Luria, 1998: 323).

Linguistic and cultural approach makes it possible to study cultural and historical values in verbal forms, accumulated experience of the language personality, as well as the national cultural mentality (Alefirenko, 2010: 16).

Linguoculturology deals with various terms, such as: concept, symbol, stereotype, key word, national behavior, cultural universality, linguistic cultural paradigm, linguistic cultural competence, etc.

There is a great demand on European citizens to be interculturally competent which is closely related to education and especially to foreign language teaching. The aim of Council of Europe language policy is not only to teach/learn a language for communication purposes, but also by effective intercultural communication to support understanding and tolerance, respect for different cultures and identities. In order to implement cultural aspects into foreign language teaching, we need to understand the basic terms and relationships between them (Reid, 2011: 43).

The purpose of the article is to carry out an in-depth analysis of the terminological system to show its ambivalence in general and the concept "tolerance" in particular from the intercultural point of view which is confirmed by the vivid 
examples; to offer the technology for integrating obtained results in creating tolerant academic environment.

Materials and methods: the analysis of the theoretical and legal bases on the issue, practical examples on ten cultures and four confessions, technology of developing intercultural communicative tolerance in the academic environment.

\section{Ambivalence of Term in Modern Terminology}

However, there is still no generally accepted definition of the notion "term". The latest definition of the term associated with the emergence and development of cognitive terminology, argues that the term is a dynamic phenomenon that is born, formed, deepened in the process of cognition, the transition from the conceptualcognitive category to the verbalized concept associated with one or another theory, conception, comprehending this or that area of knowledge and (or) activity. In connection with the historical nature of the process of cognition and consolidation of knowledge, the term gets a new definition as a verbalized sign that can have a number of options that depend on the chosen theory and the degree of knowledge depth (Leichik, 2007: 21).

It is customary to say that the meaning of the term is a special concept. This provision requires clarification. First, there are cases when one and the same lexical unit denotes (expresses) several concepts related to one or a series of terminological systems, or, on the contrary, several terms serve as a means of denoting (expressing) one and the same concept. Then immediately the question arises which of the terms adequately expresses the concept. Secondly, there may be a case where the term (lexical unit) exits but the concept is either vague (blurred) or unformed (in new areas of knowledge) or, on the contrary, has lost certainty (Leichik, 2007: 33).

In this case, we are talking about linguistic ambivalence. In addition, the formation of the term can be influenced by the emotional sphere of life. Thus, we can talk about the ambivalence of the term. The term "ambivalence" was introduced by the Swiss psychiatrist E. Bleuler in the early twentieth century.

Ambivalence (from Latin ambo - "both" and "valentia" - "power") is dual (splitting) attitude to something, in particular, the duality of the emotional experience, expressed in the fact that the same object simultaneously causes two opposite feelings in a person. E. Bleuler distinguished three types of ambivalence:

1. Emotional: simultaneously positive and negative feelings towards a person, object or event.

2. Strong-willed: endless hesitations between opposing decisions, the inability to choose between them, often leading to a refusal to make a decision at all.

3. Intellectual: the alternation of contradictory, mutually exclusive ideas in the person's reasoning.

His contemporary, Z. Freud, contributed a different meaning in the term. He regarded ambivalence as the co-existence of two originally innate, opposite deep incentives.

In psychoanalysis, ambivalence is usually understood as the complex set of feelings that a person experiences for someone. It is assumed that ambivalence is normal in relation to those whose role in the individual's life is also ambiguous (National Philosophic Encyclopedia. Electronic resource).

In the process of linguistic and cultural analysis, both components are combined: linguistic and psycho-emotional as in this case the language picture of the world is revealed to the fullest extent, and it is not just synonyms, antonyms, compatibility of words are being mastered, but the meanings behind them. Even more important is the comparative aspect of several linguocultures when the various conceptual meanings of words are studied.

$\mathrm{Yu}$. S. Stepanov notes that the concept is a calque of a Latin conceptus - a concept. However, the concept and notion are terms of different sciences. "Notion" is used mainly in logic and philosophy, whereas "concept" is a term in mathematical 
logic and currently is also used in cultural studies. The concept is a clot of culture in the person's mind; in the form of which culture enters the person's mental world. On the other hand, the concept is whereby a person enters culture himself, and in some cases influences on it (Stepanov, 2004: 42).

An important stage in the formation of the concept is an evaluation categorization. Moreover, the scale of evaluation can be different, i.e. based on specific feelings and emotions. Consequently, an evaluation categorization can have rational or emotional bases, which is expressed in the verbalization of the concept (Alefirenko, 2010: 192).

As N.N. Boldyrev notes, emotional evaluation is a certain reaction of a person to objects and phenomena of the surrounding world that affect the personal world of the speaker, his goals and attitudes, norms of behavior and which he therefore perceives as important for himself. Hence the emotional evaluation often has a purely subjective character and is associated with the psychological characteristics of the perception of specific objects and phenomena by an individual (Boldyrev, 2006: 7).

The approach of psycholinguists (A.R. Luria, A.A. Zalevskaya, A.N. Portnov, etc.) indicates that for the carriers of certain linguistic cultures, the most important may not be the categorical features captured by the classical definition but the characteristic features of objects and phenomena. (Alefirenko, 2010: 194).

Thus, the concept is a complex and multilevel mental formation which, in addition to the ordinary conceptual content, also includes evaluation and relationalevaluation meanings that show the relation of a person to a cognizable object. Therefore, the structure of the concept includes the content and evaluation components as a single synergetic whole. In the structure of the concept it is possible to distinguish several specific interdependent components (Alefirenko, 2010: 198):

1. International, representing universal values and ideas;

2. Idioethnic;

3. Social, representing the social status of communicants;

4. Group - gender, age, professional;

5. Individual-personal, reflecting the educational qualification of a person, his religious views, personal experience, speech style, etc.

The peculiarity of this or that concept is determined by the domination of some and the extinction of other features.

\section{Concept "Tolerance" in Intercultural Environment}

The events that have occurred in Europe and the world in recent years make us think about studying such topical concepts as tolerance, verity, truth, fairness, good, evil, etc. According to J. Sipko, "Here it manifests the cognitive side of the language which expresses the versatile characteristics of a person, his numerous qualities, cognitive abilities, humanism and tolerance in the aspect of ethno-cultural relations" (Sipko, 2011: 140).

"Tolerance" is one of many-sided and ambiguous concepts. On the one hand, from the point of view of scientific discourse, it can be regarded as a term belonging to the terminology of several humanitarian disciplines, such as culturology, religious studies, pedagogy, psychology, etc. On the other hand, tolerance can be represented as a concept of culture. However, the unique is the position on the polysemy and emotional coloring of a given phenomenon, often depending on perception in one or another cultural concepto-sphere. understanding it:

While analyzing the concept of "tolerance", there are basically four ways of

1. Indifference to the existence of different views and practices; 
2. Impossibility of mutual understanding (respect for another, who, at the same time, is impossible to understand and interact);

3. Condescension to the weakness of others, combined with a certain amount of contempt for them;

4. Expanding your own experience and critical dialogue.

From our point of view, all of them have negative connotations. Perhaps, it is due to the fact that the term "tolerance" is of a medical origin and was first introduced in medicine in 1953 by the English immunologist P. Medawar to denote the "tolerance" of the body's immune system to transplanted foreign tissues as a complete or partial lack of an immunological response.

Taking into account that most of the medical terminologies of the Latin origin, one can trace the relationship with such Latin terms as: tolerabilis (tolerant, tolerable, patient, enduring); tolerabiliter (tolerant, tolerable, patient); tolerans (patiently enduring, suffering); tolerantia (patience, sufferance, endurance); toleratio (ability to endure, patience); tolero (bear, endure, tolerate) (Dvoretsky, 1976: 1017).

In different languages the definition of "tolerance" is different (Tolerance: Historical Experience of Peoples in Understanding Tolerance. Electronic resource).

1. In the English language: the willingness to be tolerant, condescending; tolerance, willingness to accept behavior and beliefs that differ from one's own, even if you disagree or disapprove them. Besides, there are two concepts: "tolerance" and "toleration". The Oxford English Dictionary gives the following definition of the word "tolerance": The action or practice of tolerating; toleration; the disposition to be patient with or indulgent to the opinions or practices of others; freedom from bigotry or undue severity in judging the conduct of others; forbearance; catholicity of spirit. "Toleration", in its turn, is "an action or practice of tolerating or allowing what is not actually approved; forbearance, sufferance", as well as "allowance (with or without limitations), by the ruling power, of the exercise of religion otherwise than in the form officially established or recognized". There are also derivatives of "tolerance" denoting those who are tolerant, with tolerant behavior: a tolerant, a tolerationist, a tolerator;

2. In the Arabic language: forgiveness, indulgence, gentleness, mercy, compassion, favor, patience, favor towards others;

3. In Spanish: the ability to recognize different ideas or opinions;

4. In Chinese: to allow, accept, be generous towards other;

5. In Persian: patience, endurance, readiness for reconciliation;

6. In the Polish language: "tolerancja" is traditionally understood as the acceptance of something that in itself has a negative evaluation in a moral, aesthetic sense but for some reason has a higher order. Tolerance does not mean that it is necessary to abandon beliefs as there is objective truth, unique and absolute but there is no need to give up the right to evaluate the views and moral behavior of others (Kawęcki, 2013).

On the basis of the classical tradition, the principles of tolerance were developed by the "Polish school" from the fifteenth century by the scientists of the Krakow Academy, headed by Stanisław from Skarbimierz and P. Włodkovice, rector of the University of Krakow. P. Włodkovice got world fame by the participation in the Council of Constance where he defended Polish arguments in the dispute with the Teutonic knights.

The modern historian K. Kawęcki believes that "at present the traditional understanding of tolerance has been replaced by the ideology of tolerance that was developed by neo-Marxism of the Frankfurt School headed by Jürgen Habermas, Theodor Adorno and Herbert Marcus. In 1968 H. Markus, the chief ideologist of the ultra-left, formulated the notion of "repressive tolerance". Thus, we are talking about the transformation of tolerance with "negative" meaning into tolerance with the positive one, calling for peaceful co-existence of people professing different views but 
in fact it is a "repressive tolerance" which is called "political correctness» (Kawęcki, 2013).

7. In the Russian language the term "tolerance" (from Latin tolerantia patience) also appeared with the development of medicine. Further it is often associated with toleration, with the ability to tolerate something or someone (be selfcontrolled, endurant, persistent, be able to put up with the existence of something or somebody), be indulgent, with soft character. The word "tolerance", used in everyday speech, means the ability to endure, put up with someone else's opinion, be lenient towards the actions of others. Synonyms: liberal, tolerant, indulgent, undemanding, soft, unconditional.

In addition, one should take into account the great influence of the English language, the terminology of which has a significant influence on the formation of the vocabulary of the Russian language. However, in the Russian language tolerance and, associated with it toleration, refer, above all, to spiritual qualities.

As compared with the English language, the breadth of horizons and views becomes more important: the concept of broad-mindedness and its synonymic series, which includes the word "tolerance", relate to the classes of intellect (mental attitudes), foregiveness - affections (properties, qualities), latitude - volition (will, desire). It is an area of adequate mental perception of reality, as well as specific human traits (Obukauskaite, 2007).

8. In the late $1950 \mathrm{~s}$ in the Slovak language tolerance (tolerancia) was defined as: tolerance towards the opinions and beliefs of others, for example, religious tolerance (Krátky slovník, 2003). At the beginning of the 21 st century, the term takes on a different meaning: respect for someone else's beliefs, other people's views; patience, toleration (Slovník cudzích slov, 2005).

At the beginning of the 21 st century, the term takes on a different meaning: respect for someone else's beliefs, other people's views; patience, toleration (Slovník cudzích slov, 2005).

At present, in Slovakia, the term "tolerance" is understood as a spiritual attitude, an attitude (of an individual or collective) that allows everyone to freely express their attitude, opinions different from others. A tolerant person pursues his / her benefits, along with the benefits for other people, in order to protect his/her rights and respect the rights of others.

9. In the Ukrainian language, the term "tolerance", as well as in Russian, is associated with the "tolerant" quality and, above all, has negative connotations. For example, arbitrary use in combination with such words "moral tyranny", "patriotism", "Ukrainian", etc. (Lesia Ukrainka, V, 1956, 139); or synonymous with patience. For example, "First he [the nobleman Lewandowski] calls on the dormant partner to tolerance, restraint because the patience of the suppressed people is not unlimited (Dictionary of Ukrainian Language,1980: 179. Electronic resource).

In the later edition of the Dictionary of Foreign Words by Melchuk, the term "tolerance" (tolerantia in Latin) means an attitude toward others: strangers' views, thoughts, behavior, beliefs (Melchuk, 1985).

The Ukrainian Encyclopedia views this term as indulgence, toleration for someone's opinions, views and beliefs. For example, he acts with great tolerance for other nations and for all faith (Nechuy-Levitsky). The term tolerance is also associated with medical terminology: the loss or decrease of the ability to produce antibodies to the action of any substance or the ability of the organism to tolerate adverse effects (Ukrainian Encyclopedia. Electronic resource). This aspect is closely related to the first origin of the term in 1953.

10. In the French language, an attitude that allows others to think or act differently from you.

XLinguae, Volume 10, Issue 4, October 2017, ISSN 1337-8384, eISSN 2453-711X 
Thus, dictionaries of the XX century often associate "tolerance" with the synonym of "toleration". The dictionary of Brockhaus and Efron reduces tolerance mainly to a religious one.

The explanatory dictionary of foreign words which collected the most common lexicon entered into Russian in the XVIII-XX and the beginning of the XXI centuries, defines tolerance as a quality of tolerant (фр. tolerant, .лат. tolerans (tolerantis) - patiently enduring); tolerant, condescending to anyone or anything (Krysin, 2005: 778).

T. Margolina differentiates between the concepts of tolerance and toleration, noting that until the middle of the XX century it was treated as a passive position: enduring means giving in to someone. However, the word tolerance, although used as a synonym for toleration, carries other meanings too. Tolerance is an active social behavior which a person follows voluntarily and consciously (Margolina, 2009).

In modern Russian the term "tolerance" retains an ambivalent meaning: 1. It can be replaced by the term "toleration" (to someone else's way of life, behavior, customs, feelings, opinions, ideas, beliefs). 2. It can be independent and do not have a direct translation. Tolerance is a willingness to favorably accept and recognize the behavior, beliefs and attitudes of other people that are different from one's own, even if beliefs are not shared but are accepted as having a right to exist.

At the same time, it is necessary to emphasize the modern meaning aimed at restoring a productive dialogue with representatives of different cultures and communities.

According to the definition of the Philosophical Encyclopedic Dictionary, "Tolerance is toleration for a different kind of views, customs and habits. Tolerance is necessary in relation to the peculiarities of different peoples, nations and religions. It is a sign of self-confidence and the consciousness of the reliability of one's own positions, a sign of an open-minded ideological trend that is not afraid of comparison with other points of view and does not avoid spiritual competition» (Vasilyev, 2011: 455).

Tolerance means respect, acceptance and correct understanding of other cultures, ways of self-expression and manifestation of human individuality. Tolerance does not mean to be a concession, condescension or indulgence. The manifestation of tolerance also does not mean toleration for social injustice, rejection of one's beliefs or concessions to other people's beliefs and imposing one's beliefs on others (Ramazan, 2004: 182).

In sociology, the term denotes toleration for a different worldview, a way of life, behavior and customs. Tolerance is not equivalent to indifference. It gives others the right to live in accordance with their own worldview (Frankl, 2008: 471).

The problem of tolerance at the level of microsociology was investigated by J. Mead and G. Bloomer. To explain the tolerance, they used the description of the processes of interpersonal interaction and the theory of symbolic interactionism. Personalities and social actions are marked by symbols where relations, position and social attitude are embedded. Further, communicating individuals interpret each other's symbols. The assignment of signs and symbols is the process of identification. With the help of signs people and groups of people find their place in the system "native-alien". Tolerance can exist only in those cases when a person tries to look at the situation through the eyes of the "others". Tolerance is also provided by the creation of symbols that correspond to universal human values, such as human rights, democracy, peace.

In sociology, they most frequently study: 1 . Gender tolerance; 2 . Race and national tolerance; 3.Tolerance towards disabled people; 4.Religious tolerance; 5. Sexual Orientation Tolerance; 6. Political tolerance; 7. Educational tolerance; 8. Interclass tolerance (2003: 107). 
As L.M. Drobizheva (1998) says for evaluating tolerance in a society, it is necessary to take into account (Drobizheva, 2003: 110):

1. How much the degree of the tolerant attitude is shared and declared by social institutions and official organizations;

2. To what extent different social groups share the values of tolerance;

3. If tolerance appears in various spheres of human activity;

4. Reasons for intolerance both in social institutions and groups;

5. Possibilities of forming tolerant aims.

D.M. Bondarenko and E.B. Demintseva, etc. speak of tolerance as a fundamental universal principle on which both the world and individual societies must be based (Bondarenko et al, 2007: 153).

A key role in combating racial discrimination is assigned to such intergovernmental organizations such as the UN, OSCE and Council of Europe.

In the UN and UNESCO documents, the notion of "tolerance" has not only an effective, socially active coloring but is also seen as a condition for successful socialization (integration into the system of social relations), consisting in the ability to live in harmony, both with oneself and with the people's world (micro- and macroenvironment).

Thus, the characterization of the definition of tolerance in the Preamble of the UN Charter is as follows, "To show tolerance and live together in peace with one another as good neighbors" (Preamble of Charter of United Nations. Electronic resource).

In accordance with the Declaration of Principles of Tolerance (UNESCO, 1995), tolerance is defined as follows: the value and social norm of the civil society, manifested in the right of all individuals of the civil society to be different, ensuring sustainable harmony between confessions, political, ethnic and other social groups, respect to the diversity of different world cultures, civilizations and peoples, readiness to understand and cooperate with people who differ in appearance, language, convictions, customs and beliefs (Declaration of Principles of Tolerance. Electronic resource).

\section{Confessional Constituents of Concept "Tolerance"}

By the beginning of the XXI century among many other aspects of the problems of tolerance (social, gender, etc.) its ethnos and confessional constituents have acquired special significance. Consequently, the notion of "tolerance" needs to be analyzed in the context of various confessions.

1. Buddhism. Among Indian Buddhists tolerance was a "religious ideal." The propagator of Buddhism, the dynast Ashoka, in his ordinance stated, "You should respect the other's faith. In doing so, a person contributes to the success of his faith and supports a stranger's. In doing otherwise, he undermines the roots of his faith and damages the stranger's." (Androsov, 2001: 194)

Buddha pointed out that in relation to other religions tolerance is necessary, not to impose one's own doctrine on those who have not yet reached spiritual maturity and have not come to the preceptor on their own. The Buddha believed that every seeker has the right to self-search for spirituality. M.S. Ulanov and V.N. Badmaev believe that it became practically the first declaration of the principle in the history (Ulanov, 2016: 28).

In addition, a follower of Buddhism can also be a follower of any other religion. It is this kind of tolerance that attracts many followers to Buddhism.

2. Islam. The Prophet Muhammad had a tolerant attitude towards others and did not respond evil to evil. Particularly his tolerance to children was noted. He could quietly pray, even if his grandchildren sat down on him. He, being in the earthly bow, waited for his grandson to get off him, and then he continued praying.

XLinguae, Volume 10, Issue 4, October 2017, ISSN 1337-8384, eISSN 2453-711X 
3. Catholicism. Tolerance is understood as toleration, patience, endurance. The preference for toleration is the difference of something that does not coincide, does not correspond. (Slovníky. Electronic resource).

Manual Dictionary of Christianity stands out the term "religious tolerance". It is known that for three centuries after the birth of Christ, there were persecutions against Christians. At the beginning of the V century Christianity was accepted as the official religion in the Roman Empire but there was a huge lack of tolerance for schismatics, heretics, Mohamedans, to all who were alien to them. The peak of intolerance manifested itself in religious wars, campaigns against non-believers. Especially tragic, intolerance manifested itself during the Reformation (Príručný slovník, 2003).

Tolerance in the modern sense appeared in the XVIII century as respect, reverence for natural human rights. October 29, 1781 Emperor Josef II signed the "Pact of Tolerance" (Tolerančný pakt) which established freedom of religious worship for non-Catholics: Lutherans, Calvinists, Orthodox, living in the Habsburg monarchy.

Tolerance in the Catholic scientific literature is connected with the concept of "prejudice". Peter Laca in his article "Tolerance and social prejudices in a multicultural society of the XXI century" speaks about the role of tolerance in the life of every person: it is not difficult for us to demand a tolerant attitude towards us, but it's worse to offer to another. The more tolerance we give the more we will return. To assess the progressiveness of a society, it is possible to evaluate its maturity according the degree of the tolerant attitude of one person to another (Laca, 2012: 133).

P. Włodkovice believes that equal natural dignity and nature belong to all people, regardless of religion. In view of substantial equality, all people enjoy the same civil and natural rights that belong to Christians. For example, they have the right to property (Kawęcki, 2013).

A landmark event in the history of Europe was the French Revolution in 1789. Then the "Declaration of the Rights of Man and the Citizen" was formulated (26 VIII 1789), which initiated the growth of the "secular religion" of human rights. The revolution, referring to the principles of freedom, revolution and fraternity, in practice had nothing to do with the idea of tolerance. On the basis of the Declaration, the right to the religious freedom was violated.

The French Revolution is an extreme contradiction between the ideals proclaimed by its ideals of freedom, tolerance and concepts of intelligent and virtuous human nature and the crimes and mutual hatred that characterized it.

4. Orthodoxy. The principle of equality before God of all people, regardless of their social status and material condition is one of the main principles of Russian Orthodoxy. The significant quality is such a trait of both Russian Orthodoxy and the Russian people as patience (or as it is now customary to say - tolerance), which with special force manifests itself in the years of tragedies and upheavals (Andreev, 2012: 97).

Toleration is a Russian concept that arose from the Orthodox attitude to life. It means imitating God, who is perfect, but He tolerates our imperfection and passions not leading to perfection. The Orthodox should treat other people in the same way that God treats us all. We must tolerate the imperfection of others, realizing that we ourselves are imperfect. Thus, tolerance implies an active evaluation of reality: a clear separation of good and bad and patience with something that is not yet able to change for the better (Tolerance Differs from toleration. Electronic resource).

Perhaps this situation is connected with historical events. After the christening of Rus, the Kiev princes emphasized the continuity of the capital of the new state in the salvation of mankind and the right to become the capital of God's chosen land. This worldview formed in the Russian people such qualities as breadth of the soul, firmness and stoicism. A tremendous impact on the masses was provided 
by vivid examples of monastic morality, asceticism and monastic life. The asceticism of Sergius of Radonezh (XIV century) and Seraphim of Sarov (XVII-XVIII centuries) became a model for imitation. The Russian people not only defended their country, they defended the God-chosen land. And God's chosen nation is destined to suffer (endure - by T. Kuprina) for the salvation of the world (Udovik, 2002: 94).

However, on the part of the Orthodox Church modern sociological tolerance is criticized as a form of manipulation of people's minds with the aim of dulling, covering up negative moments for the society. For example, reducing the native population and replacing with cheap, foreign low-skilled labor. In turn, the secular public argues that if we do not learn to understand that people can look differently, eat other food, arrange their families and react to a lot of everyday things differently, we will always be in the state of the most terrible war, which can be, war at home. («Perminian Gods» Started Talking. Orthodox hierarch was opposed lessons of tolerance. Electronic resource).

In the Russian Federation, the main document for the broad definition of tolerance is the Constitution. The government is obliged to ensure equal access to health protection, education, social security, to regulate migration problems, leading to various forms of ethnic discrimination. Media reports should also cover the views of groups that may be subjected to national discrimination.

In the preamble of the Constitution of the Slovak Republic (Ústava Slovenskej republiky, 1992) it is already mentioned the natural right of a nation to self-determination, equal treatment of national minorities and ethnic groups residing on the territory the Slovak Republic. In the second chapter of the Constitution they refer to the freedom and equality of people who have their dignity and rights, which no one can select or abolish. ... The Constitution provides freedom of thought, conscience and religious faith (Ústava Slovenskej republiky, 1992: 5).

\section{Tolerance vs. Intolerance}

The opposite concept of "tolerance" is the concept of "intolerance" associated with discrimination and prejudice which represent one of the biggest obstacles in the process of mutual activity in the multicultural society of the XX century. Despite the fact that mankind has accumulated a huge intercultural experience in the modern world there are movements that bring intolerance and misunderstanding. Thus, society and people's lives are polarized, disrespect for members of society with different social identities (national, ethnic, tribal, religious) is evident (Prucha, 2010: 134).

Under social prejudices, it is necessary to understand the pre-formed dislike of the behavior of the individual or group representative. It is a "fixed, permanent attitude, a point of view with an emotional touch to certain people" (Průcha, 2010: 109). It is a complex of ideas based on prejudices that are neither grounded nor proven. The consequences of prejudice behavior lead to a violation of human rights.

A prejudice is much broader than the notion of heterostereotype, i.e. representation, opinion of simplified nature, mostly wrong, belonging to individuals or groups; a mirror effect is often detected (Kucharik, 2002).

Prejudices are often passed on from generation to generation. So, women cannot hold high positions, they drive badly; African-Americans are cheap labor and thieves; the Scots are mean; Northern peoples are cold in a relationship; the Italians constantly rest and have fun; the Russians are sullen, and so on.

In the Slovak language in the word prejudice - predsudok, the root is súdit, prefix - pred denotes in front, can indicate a temporary relationship, before the event, as it was borrowed from the Latin language. "Languages that have a grammatical basis of the Latin origin, however, consider this word incomplete and add to it the following, determining the nature of the judgment / conviction: bad or good. These

XLinguae, Volume 10, Issue 4, October 2017, ISSN 1337-8384, eISSN 2453-711X 
languages also distinguish prejudice as a judgment and prejudice as a concept of thinking" (Kucharik, 2002). Consequently, a person already has a negative opinion about other people beforehand.

Sometimes critics of tolerance use the neologism "tolerist" to implicitly insult the supporters of the ideas of tolerance, and the very notion "tolerance" is called "tolerastia" (Vasiliev, 2015: 256).

\section{Information Value of Concept "Tolerance"}

One of the problems of describing the concept "tolerance" is the development of its information value. The analysis of dictionary entries reveals its inadequate definition, as something alien, alien's opinion, behavior, etc. Therefore, to determine the object of tolerance, you can refer to specific texts of both belles-lettres and journalistic content. The concept of "tolerance" can be considered as a person's attitude to a certain phenomenon and their concretization.

One of the first multicultural actual documentary works is still the book "Journey Beyond Three Seas" by Afanasy Nikitin, a Tver merchant in the XV century, who kept a diary about his journey to India in 1469-1472. In foreign countries, he was looking for "goods to the whole of Russia and at the same time studying the life of the countries he visited on his way "beyond the three seas." He gave accurate information about the goods, climate, his route, the names of countries and cities, about the transport. In India (which historians call the museum of cults and customs, faiths and cultures, religions and languages, racial types and different ways of life) A. Nikitin showed wide tolerance, peered with the same interest and attention to various religious cultures, studied the customs and traditions of different nationalities and Caste groups, asked about important events that took place in the country.

A. Nikitin visited the main Shivaite shrine of Parvat (Pārvatī), the meaning of which he explained to the Russian reader by comparison with Jerusalem for Christians and Mecca for Muslims. Communicating with the Hindus and Muslims, he recognized his Christianity, but they did not turn away from him.

The great Russian poet Alexander Pushkin also noted the values of the culture of the West and the East, in particular, in the cycle "Imitation of the Koran". He read the Koran in Russian and French and made a poetic translation of several surahs (chapters).

Among the works of the Russian famous writers A.S. Pushkin, M.Yu. Lermontov and L.N. Tolstoy there are three equally named works "Caucasian Captive" about the life of Caucasian peoples. Thus, L.N. Tolstoy creates a realistic story about the war in the Caucasus. The writer approves the idea of tolerance through the story line of friendship between the Russian captive officer Zhilin and the Tatar girl Dina. This example makes readers think about the meaninglessness, cruelty of war and harmony based on mutual understanding and friendship.

In his story "Khor and Kalinich" I.S. Turgenev also represents tolerant judgments through the Russian people: Peter the Great was primarily a Russian man in his transformations. A Russian man is so confident of his strength and fortitude that he does not mind breaking himself. If it is good then he likes it, if it is reasonable, then give it to him but where it comes from then he does not care. His common sense willingly teases the lean German mind; but the Germans, according to Khor, are interesting people and he is ready to learn from them. (Theme of Tolerance in Russian Literature. Electronic resource).

In the story "Children of Underground" V.G. Korolenko solves the problem of tolerance in a social context. The judge's son, Vasya, made friends with the homeless and rejected children Valek and Marusya. He accepted others' pain and suffering close to his heart. Thanks to that friendship the children grew up to be decent people, respectful of any person. 
The story of the Byelorussian writer V. Bykov "The Alpine Ballad" tells us about three days of freedom of the Russian prisoner of war Ivan and the Italian girl Julia who fled from the concentration camp. And they did not even know each other's language. The Russian soldier was killed but the Italian signora carried the memory of him throughout her life and after the war found his relatives in Russia.

In the Slovak literature, the idea of tolerance is developed in connection with the idea of humanism. The prose writer Jan Kalinčiak (1822-1871) proceeds from the history of a man as an integral part of the history of the people. In the work "Slovak youth" humanism as a love for people intertwines with tolerance. The motive of the national character is connected with a tolerant attitude towards yourself, the ability to learn from your own experience. The work contains the idea of the nation as a value and a person as a one of them. (Kalinciak, 1953)

Každý národ, ktorý niečo drží na seba, nel'ahko opúšt'a svoje - hoc aké bludné presvedčenie, neprijíma odrazu pravdy, hoc aké spasitel'né, lebo sa to len dlhými bojmi, dlhým životom uviest' a verejnú všeobecnú mienku získat' si môže, čo je vel'ké, pravdivé, vznešené. Tak to bolo i na Slovensku.
Every nation that adheres to something of their own, what they believe in, hardly cease to believe in it, even if they are either mistaken or do not accept the truth but there is hope, as only a long struggle and a long life can convince the public in what it is really great, true and sublime. So it was in Slovakia.

\section{Kalinčiak, Mládenec slovenský}

Thus, the topic of tolerance in fiction is not new, it is not invented by writers; it is a part of our life.

In the publicistic texts of Russian media, the opinions of representatives of various socio-cultural groups are encountered; and each context is associated with various manifestations of tolerance (ethnic, social, gender, etc.). Moreover, the position and opinion of the subject are the basis for the situation of manifestation of tolerance. Let us consider some examples (Abolin, 2008).

According to the content, contexts are divided into those in which the subject is tolerant of anything:

"He has always been tolerant of what his emotional players say after the matches," or "Well, there is no tolerance in our country for a position that one disagrees with." (Sport Express);

And those contexts where the person is tolerant of tolerance or emphasizes hi/her intolerance to tolerance:

"We do not tolerate tolerance. ... We cannot still understand that beliefs must be denied by words and it is not necessarily to pursue for them. All this is rooted in intolerance." (Arguments and Facts).

On the other hand, a person can be tolerant in certain situations and intolerant in others: "But I do not want and cannot be tolerant of such tolerance" (Literaturnaya Gazeta/ Litrature Newpaper). Thus, the context captures the divergence of two points of view.

In the religious context, there is a link between the concepts of "tolerance" and "toleration" as it is understood in the Russian context. "Tolerance is understanding. In order to understand, one must learn as it is said in the prayer: "Lord, give me patience to endure what cannot be changed, give me the strength to change what is possible, and give me wisdom to distinguish one from another." It is the basis of tolerance. Let's be wise to distinguish what we cannot change from what we cannot endure." (Arguments and Facts). 
In the Slovak media, they write about mutual respect as a basic principle of tolerance: any approach that is not based on mutual respect leads to a restriction of rights - to inequality (akýkol’vek prístup, ktorý nie je založený na vzájomnom rešpekte, vedie k obmedzeniu práv - nerovnosti) (Č́o je vlastne tá tolerancia? Electronic resource).

However, some opinions may differ. For example, the reaction of bloggers to tolerance is related to limitations: everywhere tolerance has its limits, no country is perfect. Some call for tolerance and other similar gestures, it is just populism, the repetition of again popular modern phrases but they do not know what they really mean (V̌̌ade má tolerancia svoje hranice, žiadna krajina nie je dokonalá. Nejaké výzvy k tolerancii a podobné gestá,to je len populizmus, opakujú stále dokola tie moderné oblúbené frázy,ale sami nevedia o čom vlastne sú) (Prečo na Slovensku tolerancia nie je hodnota. Electronic resource).

The article "PRIESKUM: Tolerancia radikálnych názorov na Slovensku výrazne narástla" discusses the problem of tolerant attitude towards radical opinions. The topic in is very acute in Slovakia right now as last year after the parliamentary elections, the Nationalist party came into being who were quite radical towards all those who did not fit into their ideas. They were based on the popular views of President Tiso, the confessor, who became the head of the first Slovak Republic, which arose in 1939 after the treaty with Hitler (Prieskum: Tolerancia radikálnych názorov na Slovensku výrazne narástla. Electronic resource).

In the official statement S. Zvolenský's, a chairman of the "Conference of Catholic Biscuits" also touches on the issue of tolerance (tolerancii). However, according to S. Zvolenský, the meaning of the word in practice has narrowed to an indifferent attitude to the way of life and to the life of other people. He notes, "We live in the trap of the modern paradigm as we consciously or unconsciously believe that we can keep the public peace if we leave others alone or to the will of fate." (Zvolensky, 2014)

"But tolerance can be ostentatious, supported by prejudice and closeness. True tolerance is the result of seeking knowledge, understanding and insight. If we do not try to enter into relationships with others we do not give them the opportunity to show who they really are. This step is always a risk to some extent as a person becomes vulnerable and allows being controlled by someone else. But without this step, it is impossible to recognize a person created in the sacred image and likeness of God. Without this step it is difficult to understand the history of your community." (Zvolensky, 2014).

Thus, the expression of the forms of tolerance cannot be uniquely determined due to their multiplicity which depends, first of all, on the context situation.

\section{Facilities of Creating Tolerant Academic Environment}

In supporting tolerance the most important role is assigned to education. The increase in the number of foreign students in universities requires them to be ready to achieve intercultural communication on the basis of human dignity, openness to the perception of other cultures, the ability to resist conflicts and solve them by non-violent means. So, appropriate attention should be paid to the development of intercultural communicative tolerance, both socially and professionally significant quality.

In addition, learning foreign languages also requires tolerance to new linguistic and cultural aspects.

Learning a foreign language brings a lot of new, unknown information. Tolerance of ambiguity determines how we cope with this new, unknown information. Whether we accept them or shut them up. The ambiguity tolerance as a significant variable in the process of learning a foreign language (Stranovská, 2013: 13). 
At the same time, teaching foreign languages is a good platform for the development of intercultural communicative tolerance. The original teaching method is developed on the basis of the Ural Federal University (Yekaterinburg, Russia) within the framework of the dissertation research by Anna Beketova, who proposes the pedagogical conditions for the development of intercultural communicative tolerance: a) teaching a foreign language as a means of familiarizing with the language of another culture, and also contributing to the formation of value, behavioral points in the process of interpersonal and intercultural communication; $b$ ) application of a communicative-oriented approach to teaching foreign languages while using new communication and IT technologies created by the teacher and students; c) the creation and maintenance of a favorable psychological space in the classroom (Beketova, 2017: 10).

The developed training tutorial "Five Lessons for Developing Tolerance" ((Beketova, Kuprina, 2016) is approved and reviewed by higher educational institutions in Armenia, Brazil, Croatia, Hungary, Russia, Slovakia and the USA as a teaching and methodical project aimed at developing students' tolerance in foreign (English) language classes. In addition, the tutorial has positively evaluated by the Academic Council of the Institute of Social and Political Sciences of the Ural Federal University (Yekaterinburg, Russia) for specific scientific and applied research results. The authors of the educational methodical project have also received recognition and encouragement of the Academic Council for significant personal contribution to the development of science and education in the university.

Another important educational and methodical complex that develops the skills of tolerant behavior and intercultural dialogue is the "Introduction to Didactics of Russian Language and Intercultural Communication" with the "Hypertextual Tutorial on Intercultural Communication" published in Slovakia in 2013 and reprinted in Russia in 2015 (Petrikova, Kuprina, Gallo, 2013a, 2015b). The editions are highly evaluated both in Slovakia, Russia and abroad, they are awarded with Gold medals at the International Book Exhibitions at the Exhibition of Achievements of National Economy in Russia and in Paris, France.

\section{Conclusion}

Having considered theoretical and practical provisions related to the concept "tolerance" and the possibility of developing intercultural communicative tolerance as a necessary quality of the personality of a modern specialist, the following conclusions can be drawn.

Humanization of education requires the involvement of humanitarian disciplines that operate with such approaches as synergistic, allowing individuals to assert themselves in their synergetic position; and linguocultural, giving the opportunity to study cultural and historical values in verbal forms. In addition, the linguocultural approach operates with such notions as concept, stereotype, cultural universals, linguocultural competence.

The possession of linguocultural competence, including intercultural communicative tolerance, is a requirement of the time and is associated, first of all, with education and learning foreign languages, which are a good platform for the development of socially significant qualities.

However, it is necessary to determine the set of the qualities to be developed. To define and better understand the concept "tolerance" expressed terminologically, it is necessary to analyze it in the context of different cultures.

There are some difficulties in defining the components of the notion "term" itself, as terminology in this field of knowledge does not have precise and unambiguous definitions. Even the very word "term" is interpreted ambiguously. From the point of view of cognitive terminology, the term is presented as a dynamic

XLinguae, Volume 10, Issue 4, October 2017, ISSN 1337-8384, eISSN 2453-711X 
phenomenon that is formed in the process of cognition and transition from the concept as mental cognition to the verbalized concept.

Thus, the term is represented as a verbalized sign having a number of options depending on the context. In addition, the formation of the term can be influenced by the emotional sphere. Consequently, one can speak of the ambivalence (duality) of a term associated with an attitude to someone or something, i.e. the same phenomenon can cause opposite feelings. An important point is the evaluative categorization with rational and emotional bases which are expressed in the verbalization of the concept.

"Tolerance" is one of multiple and ambiguous concepts, terminologically embracing a different understanding. Most classical definitions have negative connotations. In addition, there is a variability of meanings depended on cultural traditions, as shown in this article on the example of 10 languages.

However, it is necessary to emphasize the modern meaning aimed at restoring a productive intercultural dialogue.

In addition, the term "tolerance" is socially significant, therefore, requiring consideration at the level of social significance, from the point of view of interpersonal interaction and the theory of symbolic interactionalism. In this context, tolerance is viewed as a universal fundamental principle on which the world community should be based.

The concept of "tolerance" is included in all documents both at the intergovernmental and countries' level.

Ethno-racial and confessional tolerance is of particular importance. Thus, the article presents the views of four confessions: Catholicism, Orthodoxy, Buddhism and Islam.

The opposite concept of "tolerance" is the concept "intolerance" associated with discrimination and prejudices being one of the major obstacles in the process of intercultural relations.

To determine the broader information meaning of the concept of "tolerance", the article cites examples from fiction and journalistic literature proving the ambiguity of the perception of the same phenomena even within one community. Thus, the interpretation of the concept depends on the context.

The important role in supporting tolerant behavior belongs to education that requires innovative teaching materials and new techniques for their implementation.

In general, as noted by K. Annan, Secretary-General of the United Nations (1997-2006), tolerance should not be confused with either passivity and conciliation or indifference. It is an active, positive and responsible attitude to human diversity. (Theme of Tolerance in Russian Literature. Electronic resource).

\section{Bibliographic references}

ABOLIN, B.I. 2008. News of the RSPU after A.I. Herzen. No. 74 -1. Available online: http://cyberleninka.ru/

ALEFIRENKO, N.F. 2010. Linguo-culturology: Value-Semantic Space of Language: Textbook. M: Flinta. 288 p. ISBN 978-5-9765-0813-2.

ANDREEV, V.I. 2012. Pedagogical Ethics: Innovative Course for Ethical SelfDevelopment. Kazan: Center for Innovative Technologies. 272 p. ISBN 5-93962-0167.

ANDROSOV, V.P. 2001. Buddha Shakyamuni. Monograph. M.: Oriental Literature, 2001. 508 p. ISBN 5-02-018236-2.

BEKETOVA, A.P. 2017. "Development of Intercultural Communicative Tolerance in Students of Telecommunication Specialties in Educational Process of University (on example of foreign language)" The thesis abstract on $\mathrm{PhD}$ (Pedagogics). Yekaterinburg: UrFU, 2017 
BEKETOVA, A.P., KUPRINA, T.V. 2016. Five Lessons for Developing Tolerance. Yekaterinburg: UrFU. 168p. ISBN 978-5-321-02485-0

BOLDYREV, N.N. 2006. Language Mechanisms of Evaluative Categorization. In: Reality, Language, Consciousness: International Interuniversity Proceedings. P.360369

BONDARENKO D.M., et al. 2007. Education as Factor of Approval of Norms of Ethno-Confessional Tolerance in Society in Conditions of Globalization (on the example of Russia, France and Tanzania). In: History and Modernity. P. 153-184. ISSN 1811-7481.

CO JE VLASTNE TA TOLERANCIA?13. januára 2015. Available online: https://dennikn.sk/blog/co-je-vlastne-ta-tolerancia/

DANCÁK P., 2012. Šoltes R., Hruška D. Prešov: PU. S. 133-258. ISBN 978-80-5550719-4.

DECLARATION of Principles of Tolerance. Available online: http://www.tolerance.ru/toler-deklaraciya.php

DICTIONARY of Foreign Words by Melnichuk, In "Slovopedia". Available online: http://slovopedia.org.ua/42/53392-0.html

DICTIONARY of Ukrainian Language. 1980. vol.10. P 179. Available online: http://sum.in.ua/

DROBIZHEVA, L.M. 2003. Sociology of Interethnic Tolerance. Moscow: Institute of Sociology RAS. 222 p. ISBN 5-89697-084-6.

DVORETSKY, I.Kh. 1976. Latin-Russian Dictionary. Moscow: "Russian Language". 1096 p. ISBN 70105-038 / 015(01) - 76 144-76.

FRANKL, V. E. 2008 Wörterbuch der Logotherapie und Existenzanalyse, Bohlau. S. 471 - 472. ISBN 3205777557, 9783205777557.

KALINCIAK, J. 1953. Mladenec slovensky. Available online: http://zlatyfond.sme.sk/dielo/110/Kalinciak_Mladenec-slovensky/2\#ixzz4ghU5OeHf KAWĘCKI, Krzysztof Ideologia tolerancjonizmu, 2013. Available online: http://prawy.pl/4304-krzysztof-kawecki-ideologia-tolerancjonizmu

KRATKY SLOVNIK slovenskeho jazyka. 2003. Bratislava: Veda, SAV. 989 c. ISBN 80-224-0750-X.

KRYSIN, L.P. 2005. Explanatory Dictionary of Foreign Words. Moscow: Eksmo. 944 p. ISBN 5-699-08073-2

KUCHARIK, R. 2002. Predsudok. Available online: https://fmfiuk.hq.sk/Informatika/Kognitivna\%20Veda/RKucharik.pdf

LACA, P. 2012. Tolerancia a sociálne predsudky v multikultúrnej realite 21 storočia. In: Humanizmus a tolerancia. Eds. p. 133-141. ISBN ISBN 978-80-555-0719-4.

LEICHIK, V.M. 2007. Terminology: Subject, Methods, Structure. Moscow: LCI. 256 p. ISBN 978-5-382-00211-8.

LURIA, L.R. 1998. Language and Consciousness. Rostov n / D .: "Phoenix". 416 p. Available online: http://mybiblioteka.su/tom3/1-7882.html

MARGOLINA, T. 2009. Tolerance is not Connivance of Vice. Tolerance is Generosity! In: Izvestiya (Russian Newpaper), 20 February. Electronic resource Available online: http://iz.ru/news/345801

NATIONAL Philosophic Encyclopedia (29 April 2017) Available online: http://terme.ru/termin/ambivalentnost.html

OBUKAUSKAITE, D.S. 2007. Tolerance and Expression of Attitude towards Other Nationalities in English and Russian Linguocultures. The thesis abstract on $\mathrm{PhD}$ (Culturology). Moscow: Moscow State University

PERMIAN GODS Started Talking. Orthodox hierarch was opposed lessons of tolerance. 18.02.2009. In: NG Religion, Available online:www.ng.ru

XLinguae, Volume 10, Issue 4, October 2017, ISSN 1337-8384, eISSN 2453-711X 
PETRIKOVA, A. - KUPRINA T. - GALLO J. 2013. Introduction Didactics of Russian Language and Intercultural Communication. Prešov: Faculty of Philosophy. 365 p. ISBN: 978-80-555-0766-8.

PHILOSOPHICAL Encyclopaedic Dictionary. 2011. Moscow: Infra-M. 576 p. ISBN 5-85270-030-4.

PREAMBLE of Charter of United Nations. Available online: http://www.un.org/ru/charter-united-nations/index.html

Preco na Slovensku tolerancia nie je hodnota. Available online: http://birdz.sk/forum/preco-na-slovensku-tolerancia-nie-je-hodnota/169997-

tema.html/

PRIESKUM: Tolerancia radikalnych nazorov na Slovensku vyrazne narastla. Available online: http://www.teraz.sk/slovensko/prieskum-tolerancia-radikalnychnazor/241807-clanok.html

PRIRUCNY SLOVNIK KRESTANSTVA. 2003. s.287. ISBN 8089063136.

PRUCHA, J. 2010. Interkulturní psychologie / Jan Prucha. 3. vyd. Praha : Portal. 224 s. ISBN 978-80-7367-709-1.

RAMAZAN,G.A. 2004. Ethnopolitology: Textbook for Students of Higher Educational Institutions. St. Petersburg. 313 p.182

REID, E. 2011. Defining terms and interconnections between culture, communication and language teaching). In: XLinguae.eu A Trimestrial European Scientific Language Review. Issue 1. Nitra. Pp.43-54. ISSN 1337-8384.

SIPKO, J. 2011. Teoretické a socialno-komunikacne vychodiska lingvokulturologie. Presov: FF PU v Presove. 320 p. ISBN 978-80-555-0371-4. SLOVNIK cudzich slov (akademicky). 2005. 2., doplnene a prepracovane vyd. Spracoval kolektiv autorov pod vedenim V. Petrackovej a J. Krausa. Preklad L. Balazova, J. Bosak, J. Genzor, I. Ripka, J. Skladana. Ed. L. Balazova - J. Bosak. Bratislava: Slovenske pedagogicke nakladatelstvo. Mlade leta 1054 p. ISBN 80-1000381-6.

SLOVNIKY. Available online: https://slovniky.lingea.sk/Ruskoslovensky/rozdielnos\%C5\%A5

STEPANOV, Yu. S. 2004. Constants: Dictionary of Russian Culture. M.: Academic Project. 992 p. ISBN 5-8291-0388-5.

STRANOVSKA, Eva 2013. Tolerancia nejednoznačnosti v cudzom jazyku, XLinguae, Volume 6, Issue 1. ISSN 1337-8384.

THEME of Tolerance in Russian Literature. Available online: http://pptcloud.ru/literatura/tema-tolerantnosti-v-russkoy-literature

TOLERANCE: Historical Experience of Peoples in Understanding Tolerance (date of access 30.04.2017). Available online: http://www.myshared.ru/slide/1090215/

TOLERANCE Differs from toleration. Available online: http://missionary.su/theology/13.htm

UDOVIK, S.L. 2002. Globalization: Semiotic Approaches. M .: "Relf-book". 480 p. ISBN 5-87983-110-8.

UKRAINIAN Encyclopedia, In Khokhopedia. Available online: http://hohlopedia.org.ua/literaturne_slovovjyvannya/page/tolerantnist.2518/

ULANOV, M.S., BADMAEV V.N. 2016. Buddhism in Context of Typology of Civilizations. In: Philosophical Sciences. No. 10.P. 28 - 40. ISSN 0235-1188.

USTAVA Slovenskej republiky, c. 460/1992 Zb. 1992. c. 5; 8 Available online: https://www.prezident.sk/upload-files/20522.pdf

VASILIEV, G.E. 2015 Introduction to Philosophy of Culture. Moscow-Berlin: Direct Media. 429 p. ISBN 9785447546250.

ZVOLENSKY, Stanislav. 2014. Prihovor predsedu Konferencie biskupov Slovenska Available online: https://www.kbs.sk/obsah/sekcia/h/dokumenty-avyhlasenia/p/zborniky-z-konferencii/c/bratislava-konferencia-kczi2014-01 
Words: 8806

Characters: 59686 (33,16 standard page)

Anna Petrikova

Mikaela Mishenkova

Faculty of Arts University of Presov in Presov,

Institute of Russian Studies ,

Presov,

Slovakia

anna.petrikova@unipo.sk

michaela.misenkova@gmail.com

Prof. Tamara Kuprina, PhD (Pedagogics),

Department of International Economics,

Department of Foreign Languages and Translation,

Ural Federal University, 19,

Mira St.,Yekaterinburg , 620002

Russia

tvkiprina@mail.ru

Anna Beketova,

Senior Lecturer,

Department of Foreign Languages and Translation,

Ural Federal University, 19,

Mira St.,Yekaterinburg , 620002

Russia

annishuara@yandex.ru 